\title{
RABA JEZIKOVNIH VIROV MED UČITELJI NA DVOJEZIČNIH ŠOLAH V PREKMURJU
}

\section{Iztok KOSEM}

Filozofska fakulteta, Univerza v Ljubljani

Ljubljana, Slovenija

\section{Attila KOVÁCS}

Inštitut za narodnostna vprašanja

Ljubljana, Slovenija

Kosem, I., Kovács, A. (2017): Raba jezikovnih virov med učitelji na dvojezičnih šolah v Prekmurju. Slovenščina 2.o, 5 (2): 179-214.

DOI: http://dx.doi.org/10.4312/slo2.0.2017.1.179-214.

$\mathrm{V}$ prispevku so predstavljeni rezultati ankete o rabi jezikovnih virov, ki je bila izvedena med učitelji na dvojezičnih šolah v Prekmurju. Anketa je bila opravljena v okviru projekta snovanja koncepta novega velikega slovensko-madžarskega slovarja, ki naj bi poleg potreb širše skupnosti upošteval tudi potrebe dvojezičnega modela poučevanja. Glavni namen ankete je bil ugotoviti, kako dobro učitelji poznajo in uporabljajo jezikovne vire, tako enojezične kot dvojezične, ter katere slovarske informacije se jim zdijo pomembne oz. koristne, pa tudi izvedeti, pri katerih sporazumevalnih aktivnostih v madžarskem jeziku imajo učitelji največ težav.

Analiza ankete je pokazala, da večina učiteljev pozna razpoložljive jezikovne vire in jih tudi uporablja pri svojem delu. Rezultati tudi kažejo, da morajo zaradi težav pri sporazumevanju $\mathrm{v}$ madžarskem jeziku učitelji uporabljati širok nabor jezikovnih virov, tako dvojezičnih kot enojezičnih. Pri tem jim ni v pomoč dejstvo, da mnogi viri, zlasti dvojezični, niso na voljo v digitalni obliki. Z vidika snovanja slovensko-madžarskega slovarja so rezultati relevantni za izbiro oblike slovarja in (delov) geslovnika kot tudi za izbiro elementov slovarske mikrostrukture, še zlasti pomembni pa so iz rezultatov izhajajoči razmisleki o vključevanju vsebin, pomembnih za produkcijo besedil oz. govor v madžarskem jeziku, postopnem objavljanju slovarja, prioritizaciji gesel in izdelavi gesel v plasteh. Takšni 
razmisleki v slovensko dvojezično leksikografijo prinašajo novosti, ki jih leksikografski trendi narekujejo, sodobni pristopi in metode pa tudi omogočajo.

Ključne besede: učitelji, dvojezično šolstvo, slovensko-madžarski slovar, anketa, raba jezikovnih virov

\section{DVOJEZIČNO ŠOLSTVO IN SLOVENSKO-MADŽARSKI SLOVAR}

Dvojezične šole na narodno mešanem območju Prekmurja obstajajo že od leta 1959. Pred tem, po letu 1945 sta ločeno delovali slovenska in madžarska osnovna šola oz. slovenski in madžarski oddelki na šolah. ${ }^{1} \mathrm{~V}$ slovenski šolski sistem je trenutno vključenih 6 dvojezičnih šol, od tega 4 dvojezične osnovne šole (OŠ I Lendava, DOŠ Dobrovnik, DOŠ Genterovci, DOŠ Prosenjakovci) in dvojezična srednja šola (DSŠ Lendava). Na narodno mešanem območju deluje tudi DOŠ II Lendava, šola s prilagojenim programom (približno 30 učencev). Temeljni del vzgojno-izobraževalnega procesa $\mathrm{v}$ dvojezičnih šolah je pouk v dveh jezikih, slovenščini in madžarščini. Šole obiskujejo tako učenci slovenske narodnosti kot učenci madžarske narodnosti. $\mathrm{V}$ učnem procesu na omenjenem območju so v rabi trije različni modeli dvojezičnega poučevanja (Nećak Lük 2013): a) model "ena oseba - en jezik", pri katerem sta v oddelku hkrati dva pedagoška delavca, eden izvaja pedagoški proces v slovenskem jeziku, drugi v madžarskem; b) ciljno-vzporedna metoda (CVM), pri kateri učitelj menja učna jezika, kar je eden vidikov priprave učne ure; in c) jezikovno-učne skupine (JUS), z dvema učiteljema, kjer se jezikovno heterogeni oddelki delijo $\mathrm{v}$ homogene skupine, $\mathrm{v}$ katerih pouk poteka pretežno $\mathrm{v}$ madžarskem oz. slovenskem jeziku.

\footnotetext{
${ }^{1}$ Vzpostavljeni model ločenih madžarskih oddelkov po letu 1945 pa se ni obnesel, ker ni nudil dovolj strokovnega znanja (pomanjkanje usposobljenega učiteljskega kadra), kakor tudi ne primernega znanja slovenskega jezika za nadaljevanje šolanja na srednješolskem nivoju. Težave je še stopnjevalo dejstvo, da v Prekmurju ni bilo srednjih šol z madžarskim učnim jezikom; najbližje srednje šole z madžarskim učnim jezikom so se nahajale v Vojvodini. Zaradi naštetih težav so se madžarski starši v prvi polovici 50. let v vedno večjem številu odločali vpisovati svoje otroke v slovenske oddelke, kar je seveda sčasoma privedlo do tega, da so madžarski oddelki ostali skoraj brez otrok. Da bi rešili nastalo situacijo, se je oblast odločila za vzpostavitev dvojezičnega modela poučevanja (Hozjan 2007).
} 
Za uspešno izvajanje dvojezičnega poučevanja in uresničevanje ciljev, kot so ohranjanje in razvijanje madžarskega jezika in kulture ter razvijanje jezikovnih zmožnosti in sposobnosti učencev $\mathrm{v}$ prvem (madžarščina) in drugem (slovenščina) jeziku ipd. (Bela knjiga o vzgoji in izobraževanju v Republiki Sloveniji, 2011), morajo dvojezične šole zagotoviti ustrezen kader, tj. učitelje, ki imajo razvito sporazumevalno zmožnost v slovenskem in madžarskem jeziku do take ravni, da ju lahko uporabljajo kot učna jezika. Ravno slabo razvita sporazumevalna zmožnost učiteljev, zlasti učiteljev »nejezikovnih « učnih predmetov $\mathrm{v}$ madžarskem jeziku, je ena od najpogosteje omenjenih pomanjkljivosti trenutnega izvajanja dvojezičnega pouka (npr. Gomivnik Thuma idr. 2010). Slabo razvita sporazumevalna zmožnost učiteljev v enem od učnih jezikov dvojezičnega izobraževanja vpliva na uspešnost izvajanja omenjenih treh modelov poučevanja in posledično na razvijanje sporazumevalne zmožnosti učencev v madžarščini oz. slovenščini, kar lahko postavi učence $\mathrm{v}$ depriviligiran položaj $\mathrm{v}$ skupnosti.

Eden od pomembnih elementov razvoja pa tudi vzdrževanja in nadgrajevanja sporazumevalne zmožnosti učiteljev in učencev $v$ madžarskem jeziku je opremljenost z ustreznimi jezikovnimi viri, kot so npr. dvojezični slovarji. Jezikovni viri imajo tudi veliko vlogo pri beleženju in razvijanju strokovne terminologije, ohranjanju kulturne identitete, ohranjanju zavesti o pripadnosti skupnosti ipd. Slovarji sodijo med osnovne jezikovne priročnike, zato so nepogrešljivi pri učenju tujih jezikov, pozitivno vlogo pa igrajo tudi v procesu usvajanja prvega jezika. Uporaba slovarjev namreč pozitivno vpliva na uspešno učenje novih besed ter pripomore k poglabljanju znanja o besedah tako na ravni pomena kot rabe (Paynter et al. 2005), bogat besedni zaklad pa je izjemno pomemben element sporazumevalne zmožnosti posameznikov - v kontekstu izobraževanja velja poudariti, da med drugim igra veliko vlogo pri šolskem uspehu, saj omogoča lažje razumevanje novih šolskih vsebin ter ima pozitiven vpliv na bralno pismenost (Paynter et al. 2005; Pečjak 2012).

Pomen razvoja jezikovnih virov za dvojezično šolstvo in dvojezično skupnost 
nasploh so $\mathrm{v}$ zadnjih letih prepoznale tudi javne institucije, in sicer $\mathrm{s}$ financiranjem dveh pomembnih projektov. Prvi projekt, E-kompetence učiteljev $v$ dvojezičnih šolah, ${ }^{2}$ sta financirala Evropska unija iz Evropskega socialnega sklada in Ministrstvo za izobraževanje, znanost in šport Republike Slovenije in je potekal od oktobra 2011 do avgusta 2013 pod vodstvom Zavoda za kulturo madžarske narodnosti. V okviru projekta je potekalo več aktivnosti, za pričujoči prispevek pa je bila najrelevantnejša izdelava e-zbirk izrazov za 15 področij, ki se poučujejo na dvojezičnih šolah. Drugi projekt, katerega del je tudi raziskava, predstavljena $\mathrm{v}$ tem prispevku, je Koncept madžarskoslovenskega slovarja: od jezikovnega vira do uporabnika,3 financirata pa ga Javna agencija za raziskovalno dejavnost Republike Slovenije in Ministrstvo za izobraževanje, znanost in šport Republike Slovenije. Gre za ciljno-raziskovalni projekt (V6-1509), ki poteka od oktobra 2015 do februarja 2018, izvajajo pa ga Filozofska fakulteta Univerze $\mathrm{v}$ Ljubljani, Filozofska fakulteta Univerze v Mariboru in Inštitut za narodnostna vprašanja. Cilj projekta je izdelati koncept velikega slovensko-madžarskega slovarja, 4 ki bi po eni strani zadostil slovarskim potrebam širše skupnosti, po drugi pa tudi vseboval informacije o slovarskih vsebinah, ki so relevantne za dvojezično izobraževanje.

Pomemben del projekta izdelave koncepta slovensko-madžarskega slovarja predstavljajo tudi raziskave med ciljnimi uporabniki, ki so $\mathrm{v}$ svetu $\mathrm{v}$ leksikografski teoriji in praksi že ustaljene (npr. Atkins 1998; Nesi 2000; Tarp 2009; Müller-Spitzer 2014), slovenski prostor pa se tovrstnih raziskav sistematično loteva šele v zadnjih letih (Arhar Holdt 2015; Čibej idr. 2015; Arhar Holdt idr. 2016, 2017). Tako je tudi zelo malo raziskav o uporabi jezikovnih virov ter potrebah in pričakovanjih deležnikov $\mathrm{v}$ dvojezičnem

\footnotetext{
2 http://www.e-kompetencia.si/

3 http://www.cjvt.si/komass/

4 Čeprav je $\mathrm{v}$ naslovu projekta omenjen madžarsko-slovenski slovar, je analiza stanja pokazala, da se je dejansko potrebno osredotočiti na slovensko-madžarski del, saj v Budimpešti na univerzi ELTE že poteka izdelava madžarsko-slovenskega slovarja. Kljub temu je uradni naslov projekta zaradi proceduralnih in administrativnih pravil moral ostati nespremenjen.
} 
šolstvu, ki bi bili ravno največja skupina uporabnikov novega slovarja. Z raziskavo, predstavljeno $\mathrm{v}$ tem članku, smo želeli delno zapolniti ta manko, pridobiti vedenje o težavah in potrebah učiteljev $\mathrm{v}$ dvojezičnem modelu poučevanja ter relevantne informacije in rešitve vključiti v koncept slovarja.

\section{ANKETA O RABI JEZIKOVNIH VIROV MED UČITELJI}

Glavni namen ankete je bil ugotoviti, kako dobro učitelji poznajo in uporabljajo jezikovne vire, tako enojezične kot dvojezične, ter katere slovarske informacije se jim zdijo pomembne oz. koristne. $V$ ta namen smo izdelali izčrpne sezname enojezičnih virov za slovenščino in madžarščino ter dvojezičnih virov $\mathrm{s}$ tema dvema jezikoma, vključili pa smo tudi sodobne jezikovne vire neslovarskega tipa (npr. korpuse, prevajalske baze). Pri vprašanjih smo vedno ponudili možnost » Drugo «, kjer so učitelji lahko navedli morebitne druge enojezične ali dvojezične vire, ki jih poznajo oz. uporabljajo.

Želeli smo tudi izvedeti, pri katerih sporazumevalnih aktivnostih v madžarskem jeziku imajo učitelji največ težav, saj je to lahko koristno vodilo pri izbiri informacij za vključitev v slovarska gesla. Informacije smo pridobili s tremi vprašanji: prvo je bilo izbirnega tipa, ponujene so bile glavne sporazumevalne aktivnosti; drugo je bilo podvprašanje prvemu, v katerem so učitelji lahko pojasnili odgovor na prvo vprašanje, in je bilo odprtega tipa; tretje vprašanje se je nanašalo na konkretno situacijo, in sicer težave pri uporabi madžarskega jezika pri pouku oz. njihovem delu.

Anketo smo izvedli v aplikaciji 1 ka za spletno anketiranje, 5 pri čemer smo jo najprej testirali med člani projektne skupine. Anketa je bila odprta dva meseca, med 4. januarjem in 4. marcem 2017. Po šolah smo jo promovirali preko ravnateljev, ki so nagovorno sporočilo poslali celotnemu učiteljskemu zboru. Sporočilo je bilo poslano dvakrat, prvič v začetku januarja, drugič pa kot opomnik sredi februarja; dejansko je največji delež učiteljev anketo izpolnil po

5 https://www.1ka.si/ 
prejetju opomnika. Ker so med učitelji na dvojezičnih šolah tudi taki, ki enako obvladajo oba jezika ali pa so materni govorci madžarščine, smo ponudili možnost reševanja bodisi v slovenščini bodisi v madžarščini. Za namene analize in kodiranja smo po zaključeni anketi madžarske odgovore pri vprašanjih odprtega tipa prevedli v slovenščino.

Tudi analizo smo opravili v aplikaciji 1ka, saj le-ta ponuja različne možnosti obdelave podatkov, tudi določene napredne statistične izračune. Za izračun statistične pomembnosti smo uporabili reziduale. ${ }^{6}$ Po priporočilu avtorjev priročnika 1ka smo uporabili prilagojene reziduale (angl. adjusted residuals), ki naj bi bili najustreznejši za statistične analize. V prispevku tako ob izračunu statistične pomembnosti vedno navedemo vrednost prilagojenega reziduala (AR), za lažje tolmačenje vrednosti pa navajamo pojasnilo iz priročnika 1ka:

- $\quad$ nad 1.o pomeni določeno povečanje in pozornost,

- nad 2.0 (gre za poenostavitev vrednosti 1.96) pomeni statistično značilno razliko (sign<0.05), torej se z razmeroma majhnim tveganjem reziduali razlikujejo od nič

- nad 3.o pa pomenijo že močno odstopanje (sign<<.01), kar pomeni, da so reziduali skoraj zagotovo različni od nič in se torej v celici nekaj 'dogaja'.«

\section{REZULTATI}

Anketo je v celoti izpolnilo 117 učiteljev in učiteljic, 7 delno pa še nadaljnjih 17. Večina od teh 17 je anketo prenehala reševati pri vprašanju številka 10, tako da o njih nismo pridobili demografskih podatkov, a smo njihove odgovore pri analizi vseeno upoštevali. Poleg tega je treba upoštevati tudi to, da na nekatera

\footnotetext{
${ }^{6}$ Rezidual je razlika med dejansko frekvenco $\mathrm{v}$ določeni celici in teoretično frekvenco, kakršna bi bila, če spremenljivki dvorazsežne tabele $\mathrm{v}$ tej celici ne bi bili povezani (predpostavka ničelne domneve)«. Spletna pomoč 1ka, Analize-Statistike:

https://www.1ka.si/db/24/308/Prironiki/Reziduali_v_tabelah/?\&from1ka=1\&cat=285\&p1=226 $\& \mathrm{p} 2=735 \& \mathrm{p} 3=789 \& \mathrm{p} 4=794 \& \mathrm{p} 5=861 \& \mathrm{id}=861 \&$ from $1 \mathrm{ka}=1$

7 V nadaljevanju se oblika »učitelj« vedno nanaša na učitelje in učiteljice, razen v primerih, ko se opravljajo primerjave glede na spol in so podatki za učitelje in učiteljice navedeni ločeno.
} 
vprašanja odgovor ni bil obvezen oz. so se respondenti lahko odločili, da nanj ne bodo odgovarjali. Posledično je pri analizi posameznih vprašanj vedno ponujena informacija o številu veljavnih odgovorov in ne respondentov.

108 učiteljev (81 \%) je rešilo anketo v slovenskem jeziku, 26 (19 \%) pa v madžarskem. Ker gre za dvojezično skupnost, težko rečemo, do kakšne mere ta podatek kaže na materni jezik učitelja, je pa najbrž dober pokazatelj jezika, v katerem učitelji raje komunicirajo.

Večina respondentov je bila žensk (95 oz. 81 \%), moških respondentov je bilo 22 oz. $19 \%$. Največ respondentov je bilo starih od 36 do 45 let (37\%), od 46 do 55 let ( $29 \%$ ) in od 26 do 35 let ( $24 \%$ ), precej manj je bilo mlajših od 26 let (3 \%) oz. starejših nad 56 let (7 \%). V povprečju so bili moški precej mlajši od žensk, npr. 3 oz. 14 \% jih je bilo mlajših od 26 let (v tej skupini ni bilo nobene ženske), 7 oz. 33 \% jih je bilo starih od 26 do 35 let (žensk 22 \%), 6 oz. 29 \% pa od 36 in 45 let (žensk $39 \%$ ).

Velika večina vprašanih ( 85 učiteljev oz. 73 \%) poučuje na osnovni šoli, ostali pa bodisi na gimnaziji (18 oz. $15 \%$ ) ali srednji poklicni šoli (14 oz. 12 \%). Takšno razmerje je seveda tudi posledica dejstva, da je v Prekmurju pet dvojezičnih osnovnih šol in samo ena dvojezična srednja šola, ki pa ponuja tako splošne kot poklicne programe. Anketo so rešili učitelji različnih predmetov oz. različnih razredov/letnikov (dejansko je zastopan vsak šolski predmet oz. šolska raven), največ je bilo učiteljev razrednega pouka (26), madžarskega jezika (24),8 matematike (14), slovenskega jezika (9), geografije (7) in zgodovine (7).

V nadaljevanju podajamo odgovore po posameznih vprašanjih, pri določenih

\footnotetext{
8 Madžarski jezik se na dvojezičnih osnovnih šolah in dvojezični srednji šoli poučuje na dveh različnih nivojih: madžarščina kot prvi jezik (materinščina) in madžarščina kot drugi jezik. Na dvojezični srednji šoli v Lendavi se pri madžarščini kot drugem jeziku izvaja zunanja diferenciacija. Zaradi tega je sorazmerno veliko število učiteljev madžarskega jezika v primerjavi z učitelji slovenskega jezika, saj je več skupin učencev oz. dijakov, ki jih poučujejo učitelji madžarskega jezika. Nekateri učitelji so tudi dvopredmetni in poleg madžarščine poučujejo tudi druge predmete.
} 
vprašanjih pa tudi podatke o statistično pomembnih povezavah z odgovori pri relevantnih drugih vprašanjih.

KATERO OBLIKO JEZIKOVNIH VIROV NAJRAJE UPORABLJATE (N=134)?

\begin{tabular}{l|l}
\hline Odgovor & Odstotek \\
\hline kombinacijo tiskane in digitalne & $72 \%$ \\
\hline digitalno (računalnik) & $16 \%$ \\
\hline tiskano & $8 \%$ \\
\hline digitalno (tablični računalnik) & $3 \%$ \\
\hline digitalno (mobilnik) & $1 \%$ \\
\hline
\end{tabular}

Kot je razvidno iz tabele, večina učiteljev iz vseh starostnih skupin najraje uporablja kombinacijo tiskanih in digitalnih jezikovnih virov. Več kot polovica učiteljev, ki uporabljajo jezikovne vire samo na računalniku, je starih med 26 in 35 let. Nekako pričakovano je manj učiteljev, ki jezikovne vire najraje uporabljajo na tabličnih računalnikih ali mobilnih telefonih; po drugi strani pa je malce presenetljivo, da so to učitelji stari med 36 in 45 let (tablica; trije učitelji) in nad 56 let (mobilnik; 1 učitelj). Samo tiskano obliko najraje uporablja 8 \% učiteljev, starih med 36 in 55 let. Nobeden od učiteljev, mlajših od 36 let, ni izbral tega odgovora. 
KATERE ENOJEZIČNE VIRE ZA SLOVENŠČINO POZNATE (N=134) OZ. UPORABLJATE V RAZREDU ALI PRI PRIPRAVI NA PEDAGOŠKO DELO $(\mathrm{N}=119)$ ?

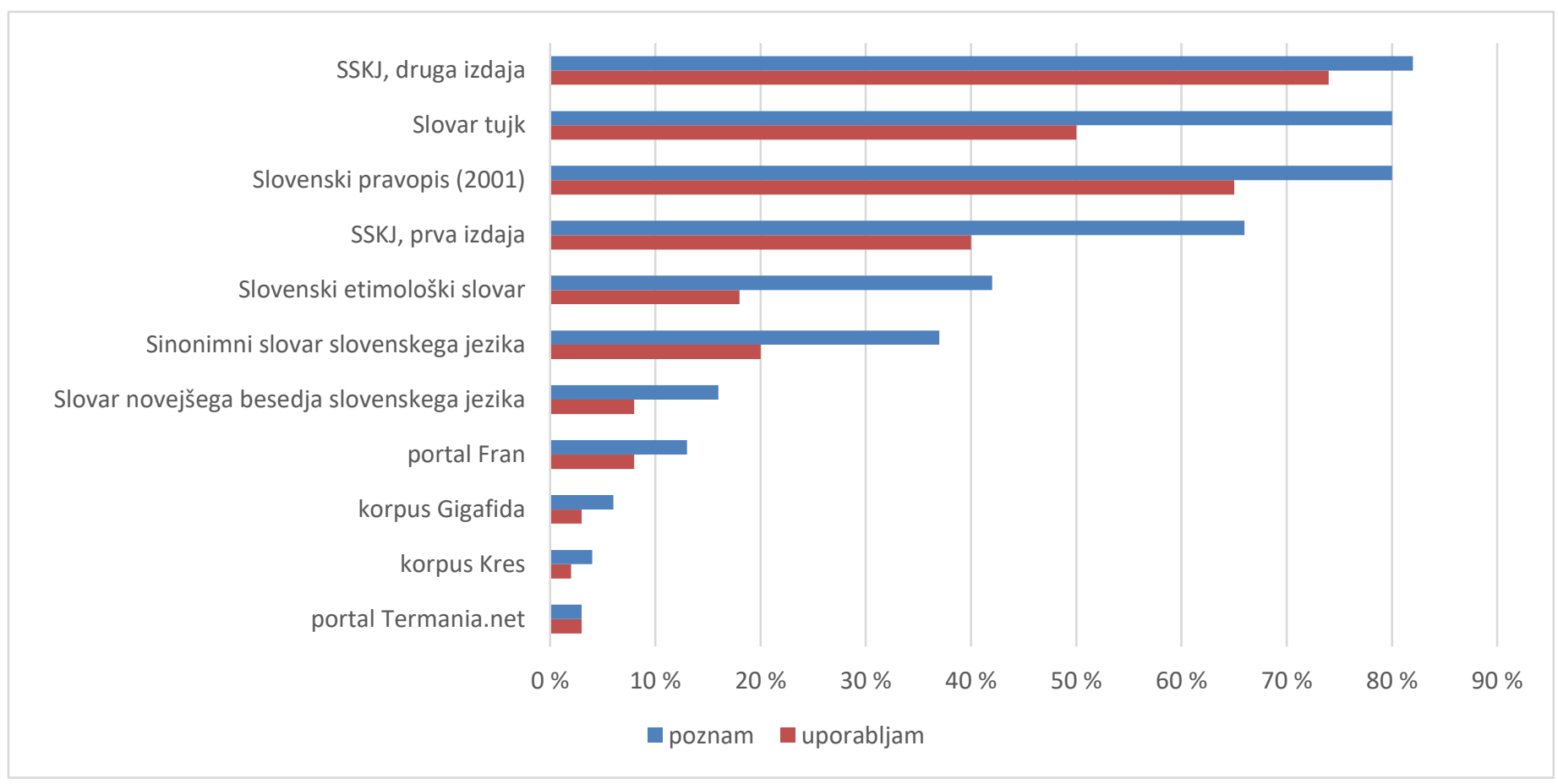


Večina učiteljev pozna temeljne jezikovne vire za slovenščino, kot sta obe izdaji SSKJ (prvo izdajo pozna 66 \% učiteljev, drugo pa 82 \%)9 in Slovenski pravopis (80 \%), pa tudi Slovar tujk (8o \%). Od omenjenih virov jih največ uporablja drugo izdajo SSKJ (74 \%) in pravopis (65\%), sledita Slovar tujk in pa prva izdaja SSKJ. Precej manj učitelji poznajo, še manj pa uporabljajo, Slovenski etimološki slovar in Sinonimni slovar slovenskega jezika. Zelo slabo poznani so učiteljem viri, kot so Slovar novejšega besedja slovenskega jezika (pozna 16 \% učiteljev, uporablja $8 \%$ ), portal Fran (pozna $13 \%$, uporablja $8 \%$ ), korpusa Gigafida (pozna $6 \%$, uporablja $3 \%$ ) in Kres (pozna $4 \%$, uporablja $2 \%$ ) ter portal Termania (pozna in uporablja $3 \%$ učiteljev).

Do statistično pomembnih razlik med učitelji in učiteljicami prihaja samo pri uporabi Slovenskega pravopisa ( $\mathrm{AR}=2.175$ ), katerega uporablja precej večji delež učiteljic (69 \%) kot učiteljev (42\%). Precejšnje razlike so tudi pri uporabi Slovarja tujk (55 \% učiteljic in 32 \% učiteljev) in SSKJ2 (71 \% učiteljic in 84 \% učiteljev), vendar pa niso statistično pomembne.

Pri starostnih skupinah se statistično pomembne razlike pojavljajo le pri Sinonimnem slovarju slovenskega jezika in portalu Termania. Sinonimni slovar nadpovprečno pogosto uporabljajo učitelji, stari med 46 in 55 let $(38 \%$, AR = 2.236), zelo redko pa učitelji, stari med 26 in 35 let ( $8 \%, A R=-2.150)$. Učitelji, stari med 46 in 55 let, statistično izstopajo tudi pri uporabi portala Termania $(\mathrm{AR}=2.143)$.

Tudi med učitelji na osnovni šoli, gimnaziji ali srednji poklicni šoli ni veliko razlik, statistično pomembne razlike je moč opaziti le pri uporabi Slovenskega pravopisa, in sicer ga uporablja nadpovprečno visok delež učiteljev na osnovnih šolah $(72 \%, A R=2.894)$ in relativno majhen delež učiteljev na gimnaziji (38 $\%, \mathrm{AR}=-2.379)$.

\footnotetext{
9 Gre za dokaj nenavaden rezultat, če upoštevamo, da je v času izvajanja ankete od izdaje SSKJ2 minilo šele nekaj let, poleg tega pa takrat slovar na spletu še ni bil prosto dostopen (kodo za spletni dostop se je dobilo z nakupom tiskane verzije). Rezultat bi veljalo preveriti z drugo obliko študije, npr. intervjuji, lahko pa rečemo, da sugerira preferenco učiteljev po ažurnosti pri enojezičnih virih za slovenščino, hkrati pa preferenco po tiskani obliki enojezičnih slovarjev (kar je do določene mere v skladu z uporabo dvojezičnih virov).
} 
KATERE ENOJEZIČNE VIRE ZA MADŽARŠČINO POZNATE (N=114) OZ. UPORABLJATE V RAZREDU ALI PRI PRIPRAVI NA PEDAGOŠKO DELO (N=95)?

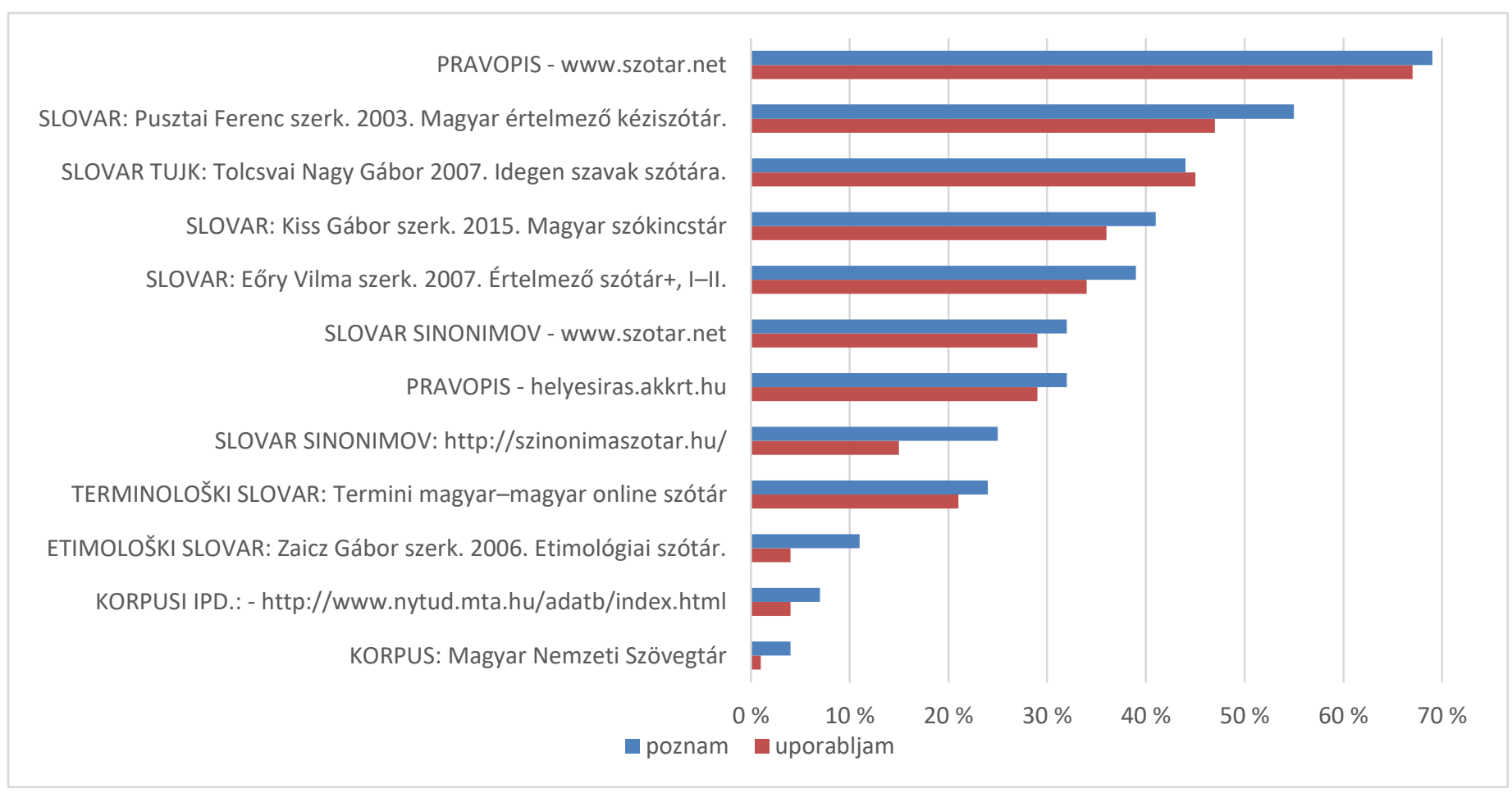


Nekoliko slabše učitelji poznajo enojezične jezikovne vire za madžarščino. Največ učiteljev pozna in uporablja pravopis na strani www.szotar.net (69 \% pozna, $67 \%$ uporablja). 55 \% pozna slovar Ferenca Pusztaija iz leta 2003 (uporablja ga 47 \% učiteljev), ki je sicer najstarejši od enojezičnih madžarskih slovarjev, navedenih v anketi. Vse ostale vire pa pozna/uporablja manj kot 50 \% učiteljev, se pa spet dokaj visoko med viri pojavlja slovar tujk, ki ga uporablja 45 \% učiteljev. Slovarja sinonimov sta na prvi pogled med učitelji manj poznana, saj ju pozna $32 \%$ (www.szotar.net) $\quad$ oz. $25 \%$ učiteljev (http://szinonimaszotar.hu/), vendar pa je več kot polovica vseh učiteljev (33 od 65), ki so izbrali ta odgovor, izbrala samo enega od obeh odgovorov, kar pomeni, da je celotni delež učiteljev, ki poznajo in uporabljajo sinonimni slovar (enega od naštetih dveh), precej višji. Precej manj učiteljev pozna oz. uporablja terminološki slovar, etimološki slovar in korpuse.

Do statistično pomembnih razlik med učitelji in učiteljicami prihaja pri uporabi sinonimnega slovarja na szotar.net $(A R=2.162)$. Poleg tega so opazne razlike med učiteljicami in učitelji v rabi slovarja Gáborja Kissa iz 2015, slovarja Ferenca Pusztaija iz 2003, pravopisa (helyesiras.akkrt.hu) in slovarja tujk; vse omenjene vire uporablja večji delež učiteljic kot učiteljev, vendar pa razlike niso statistično pomembne.

Pri starostnih skupinah se statistično pomembne razlike pojavljajo le pri učiteljih, starih med 26 in 35 let in med 46 in 55 let: prva skupina nadpovprečno redko uporablja slovar tujk ( $\mathrm{AR}=-\mathbf{2 . 6 5 6})$, druga pa nadpovprečno pogosto slovar sinonimov na szotar.net $(\mathrm{AR}=2.759)$ in slovar tujk (prilagojeni rezidual $=2.130$ ).

Do statistično pomembnih razlik prihaja tudi med učitelji na različnih šolah. Tako nadpovprečno velik delež učiteljev na osnovnih šolah uporablja slovar Gáborja Kissa (močno odstopanje, AR = 3.415), slovar sinonimov na szotar.net $(\mathrm{AR}=2.929)$ in slovar Ferenca Pusztaija $(\mathrm{AR}=2.429)$. Po drugi strani zelo malo učiteljev na gimnaziji uporablja omenjeni slovar in slovar sinominov, na srednji poklicni šoli pa ju sploh ne uporabljajo. Ravno obratno pa velja za slovar tujk, ki ga uporablja nadpovprečno velik delež učiteljev na gimnaziji ( $\mathrm{AR}=1.942)$ oz. srednji poklicni šoli (2.055), in zelo majhen delež učiteljev na osnovnih šolah (močno odstopanje, $\mathrm{AR}=-3.019$ ). 
KATERE DVOJEZIČNE JEZIKOVNE VIRE PARA SLOVENŠČINA-MADŽARŠČINA POZNATE $(\mathrm{N}=128)$ OZ. UPORABLJATE V RAZREDU ALI PRI PRIPRAVI NA PEDAGOŠKO DELO (N=119)?

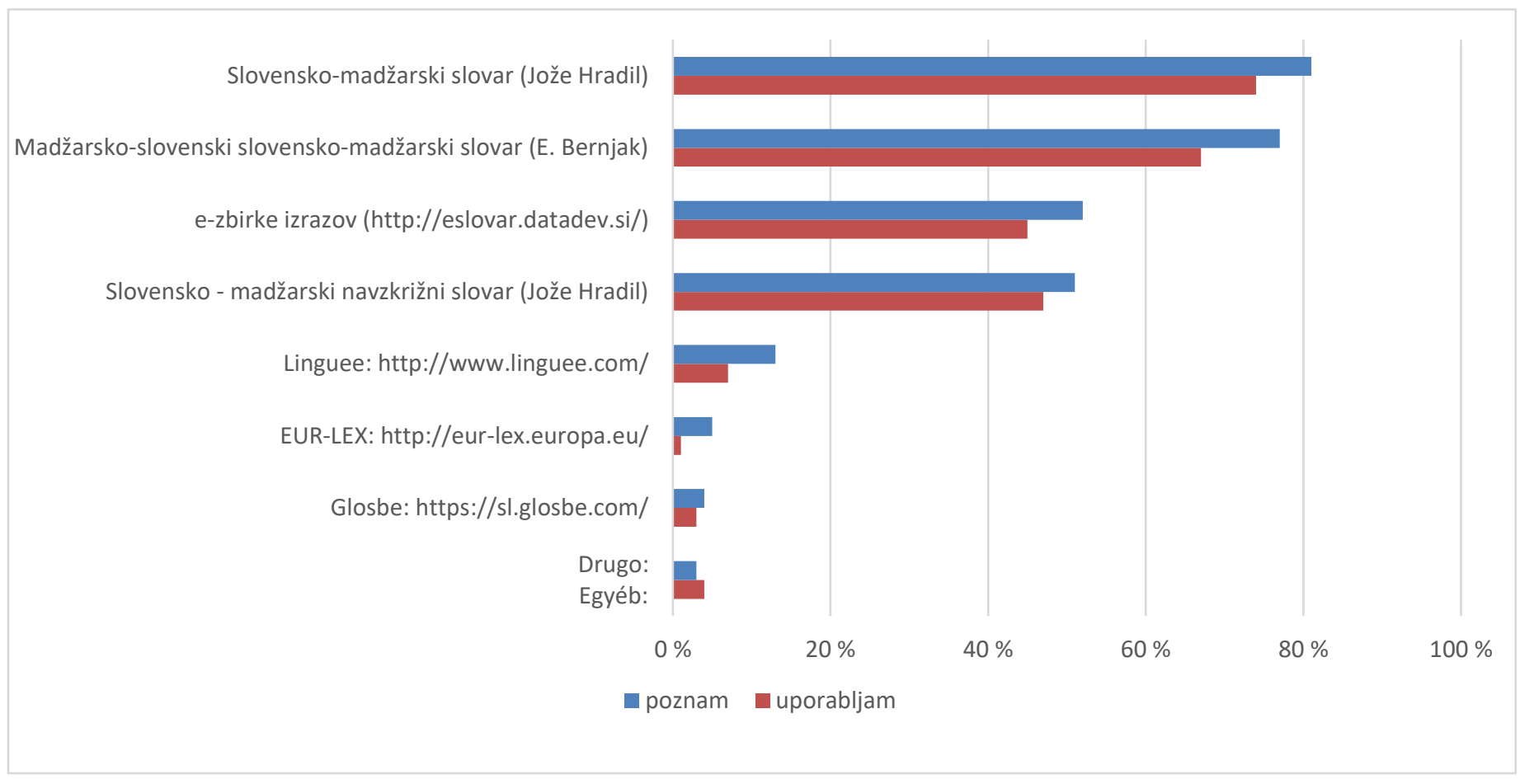


Veliko učiteljev pozna in uporablja obstoječe slovensko-madžarske in madžarsko slovenske slovarje, prednjačita Hradilov Slovensko-madžarski slovar (pozna ga $81 \%$ učiteljev, uporablja pa $74 \%$ ) in dvosmerni slovar Elizabete Bernjak (pozna 77 \% učiteljev, uporablja 67 \%). Nekoliko manj učiteljev pozna/uporablja e-zbirke izrazov (52 \% pozna, $45 \%$ uporablja) in Hradilov navzkrižni slovar ( $51 \%$ pozna, 47 \% uporablja). Zelo malo učiteljev pozna oz. uporablja ostale tri spletne vire, ki ponujajo slovensko-madžarsko kombinacijo. Pod Drugo so učitelji navedli dict.com (2 učitelja) in iate.europa.eu (1 učitelj).

Zanimivo je, da so statistično pomembne razlike med učitelji, ki so reševali anketo v slovenščini, in učitelji, ki so jo reševali v madžarščini, saj precej večji delež slednjih pri svojem delu uporablja Hradilov navzkrižni slovar (v madžarščini, $76 \%, A R=3.262$; v slovenščini, $39 \%, A R=-3.262)$ in slovar E. Bernjak (v madžarščini, 84 \%, AR = 2.010; v slovenščini, 63 \%, AR = -2.010).

Statistično pomembne povezave najdemo med učitelji, ki uporabljajo tako slovar Ferenca Pusztaija kot Hradilov navzkrižni slovar (73 \%, AR = 3.299), slovar E. Bernjak ( $89 \%, A R=2.331)$ ali e-zbirke izrazov $(61 \%, A R=1.996)$. Tudi korelacije med uporabniki slovarja sinonimov na szotar.net in Hradilovega navzkrižnega slovarja $(71 \%, \mathrm{AR}=2.107)$, slovarja E. Bernjak (89 $\%, A R=2.388)$ ali e-zbirke izrazov $(68 \%, A R=2.202)$ so statistično pomembne. Podobno so statistično pomembne povezave med učitelji, ki uporabljajo pravopis na helyesiras.akkrt.hu in Hradilov Slovensko-madžarski slovar (96 \%, AR = 2.754) ali Hradilov navzkrižni slovar (73 \%, AR = 2.199), pa tudi med učitelji, ki uporabljajo tako slovar tujk na szotar.net kot Hradilov navzkrižni slovar (70 \%, AR = 2.556) oz. e-zbirke izrazov $(63 \%, A R=2.019)$.

Statistično pomembne razlike med učitelji in učiteljicami se kažejo v uporabi Hradilovega navzkrižnega slovarja, ki ga uporablja veliko večji delež učiteljic ( $55 \%, \mathrm{AR}=2.386)$ kot učiteljev ( $25 \%$ ), nekoliko manj statistično pomembne razlike pa so tudi v uporabi slovarja E. Bernjak (76 \% učiteljic, AR = 1.905; $55 \%$ 
učiteljev).

Pri starostnih skupinah statistično izstopajo le učitelji, stari med 46 in 55 let, in nad 56 let. Pri prvih jih $\mathrm{v}$ primerjavi $\mathrm{z}$ ostalimi starostnimi skupinami nadpovprečno veliko uporablja slovar E. Bernjak ( $94 \%$, močno odstopanje, AR = 3.175), precej veliko pa tudi Hradilov navzkrižni slovar ( $65 \%, \mathrm{AR}=1.980)$ in e-zbirke izrazov ( $61 \%, A R=1.928)$. Po drugi strani učitelji, stari nad 56 , zelo redko uporabljajo Hradilov navzkrižni slovar $(13 \%, \mathrm{AR}=-2.178)$.

Delež učiteljev na osnovnih šolah, ki uporabljajo slovar E. Bernjak (78 \%), je nadpovprečno visok in statistično pomemben $(\mathrm{AR}=2.401)$. Po drugi strani pa je statistično pomemben tudi nizek delež učiteljev na gimnaziji (40 \%, močno odstopanje, AR = -3.003), ki uporabljajo omenjeni vir. Podobne razlike med učitelji na osnovnih šolah ( $51 \%$ ) in gimnaziji ( $27 \%$ ) je moč opaziti tudi pri rabi e-zbirk izrazov, a le-te niso statistično pomembne.

PRI KATERI SPORAZUMEVALNI AKTIVNOSTI V MADŽARSKEM JEZIKU IMATE NAJVEČ TEŽAV? $(\mathrm{N}=124)^{10}$

\begin{tabular}{l|c|c}
\hline Aktivnost & Št. odgovorov & Odstotek \\
\hline govorjenju & 24 & $19 \%$ \\
\hline pisanju & 45 & $36 \%$ \\
\hline branju & 2 & $2 \%$ \\
\hline poslušanju & 2 & $2 \%$ \\
\hline Nimam težav & 65 & $52 \%$ \\
\hline
\end{tabular}

Učitelji imajo največ težav pri pisanju in govorjenju v madžarskem jeziku. Razlike med moškimi in ženskami, starostnimi skupinami in učitelji z različnih

${ }^{10}$ Možnih je bilo več odgovorov. 
šol niso statistično pomembne.

Zanimivo je, da učitelji s težavami pri sporazumevanju v madžarskem jeziku, zlasti govorjenju in pisanju, praviloma dvojezične jezikovne vire uporabljajo redkeje kot učitelji, ki s sporazumevanjem nimajo težav. Statistično pomembne razlike so predvsem pri rabi Hradilovega navzkrižnega slovarja (težave pri govorjenju, $29 \%, \mathrm{AR}=-1.998$; nima težav, $56 \%$, AR = 1.915), nekoliko manj pa pri rabi e-zbirk izrazov (težave pri pisanju, $36 \%$, AR = -1.502; nima težav, 55 $\%, \mathrm{AR}=2.159$ ) in slovarja $\mathrm{E}$. Bernjak (težave pri govorjenju, $57 \%, \mathrm{AR}=-1.231$; nima težav, $76 \%, \mathrm{AR}=1.852$ ). Razloge za ta rezultat gre mogoče iskati tudi $\mathrm{v}$ tem, da obstoječi dvojezični jezikovni viri nimajo veliko vsebin, ki bi bile naravnane na jezikovno produkcijo.

Podoben vzorec opazimo tudi pri uporabi enojezičnih virov za madžarski jezik. Slovar Gáborja Kissa iz leta 2015 (43 \%), slovar Ferenca Pusztaija iz 2003 (55 \%), pravopis na szotar.net ( $79 \%, \mathrm{AR}=2.599$ ), pravopis na helyesiras.akkrt.hu (38\%, AR = 2.142), slovar sinonimov na szotar.net (38\%) in slovar tujk (52 \%) uporablja večji delež učiteljev, ki nima težav pri sporazumevanju v madžarskem jeziku, kot učiteljev, ki imajo največje težave pri katerikoli od ostalih aktivnosti, pri čemer so razlike pri obeh pravopisih statistično pomembne. Statistično pomemben je tudi podatek, da zelo nizek delež učiteljev, ki imajo največje težave s pisanjem, uporablja pravopis na szotar.net (50 \%, AR = -2.394) oz. da ti učitelji sploh ne uporabljajo slovarja sinonimov na http://szinonimaszotar.hu/ (o \%, AR = -2.551).

Manj odstopanj najdemo pri uporabi enojezičnih virov za slovenski jezik, saj je tam statistično pomemben samo zelo nizek delež učiteljev, ki nimajo težav pri sporazumevanju $\mathrm{v}$ madžarskem jeziku in uporabljajo SSKJ1 (31 \%, $\mathrm{AR}=-1.939)$. 
ZAKAJ MENITE, DA JE TAKO? $(\mathrm{N}=56)^{11}$

\begin{tabular}{l|c}
\hline preredka raba & 13 \\
\hline pravopis & 11 \\
\hline slab besedni zaklad & 10 \\
\hline premalo let učenja & 5 \\
\hline težave pri govoru & 5 \\
\hline premalo pisanja & 4 \\
\hline ni materni jezik & 4 \\
\hline nova slovnica & 4 \\
\hline premalo strokovnih podlag & 2 \\
\hline pomanjkanje virov & 2 \\
\hline težave pri pisanju & 2 \\
\hline
\end{tabular}

Med razlogi za težave pri sporazumevanju v madžarskem jeziku so učitelji največkrat omenili preredko rabo jezika, zahteven pravopis in slab besedni zaklad, več učiteljev je omenilo tudi premalo let učenja in težave s slovnico. Preredko rabo so navedli tako učitelji, ki so poročali o največjih težavah $\mathrm{s}$ pisanjem (10) oz. govorjenjem (6). ${ }^{12}$ Podobno velja za razloga slab besedni zaklad (težave z govorjenjem - šest učiteljev; težave s pisanjem - pet učiteljev) in premalo let učenja (težave z govorjenjem - štirje učitelji; težave s pisanjem pet učiteljev). Pravopis so kot razlog za težave navedli predvsem učitelji, ki imajo največ težav s pisanjem (10).

\footnotetext{
${ }^{11}$ Podani so samo najpogostejši odgovori.

12 Vsota odgovorov se pri nekaterih razlogih razlikuje od številke v tabeli, saj so nekateri učitelji našteli več različnih razlogov za težave.
} 


\section{KAJ VAM PRI UPORABI MADŽARSKEGA JEZIKA PRI POUČEVANJU POVZROČA NAJVEČ PREGLAVIC? $(\mathrm{N}=67)^{13}$}

\begin{tabular}{l|l}
\hline strokovni izrazi & 21 \\
\hline pravopis & 9 \\
\hline slab besedni zaklad & 6 \\
\hline pomanjkanje kvalitetnih jezikovnih virov ali učbenikov & 5 \\
\hline prevajanje & 3 \\
\hline govor & 3 \\
\hline slovnica & 3 \\
\hline pisanje & 3 \\
\hline slabo znanje učencev & 2 \\
\hline
\end{tabular}

Nekoliko drugačno sliko težav najdemo pri vprašanju o največjih težavah pri uporabi madžarskega jezika pri poučevanju. Največ učiteljev je kot največjo težavo navedlo strokovne izraze oz. terminologijo, precej pa tudi pravopis, slab besedni zaklad in pomanjkanje kvalitetnih jezikovnih virov in učbenikov. Zanimivo je, da je kar 19 učiteljev, ki so odgovorili, da nimajo težav pri sporazumevanju v madžarskem jeziku, tu navedlo vsaj eno od težav, največkrat strokovne izraze, prevajanje in pomanjkanje kvalitetnih jezikovnih virov in učbenikov. Poleg tega samo polovica učiteljev (10), ${ }^{14}$ ki je navedla težave $\mathrm{S}$ strokovnimi izrazi, uporablja e-zbirke izrazov, katerih namen je ravno popis terminov, uporabljenih pri različnih šolskih predmetih, in njihovih madžarskih prevodov.

\footnotetext{
13 Podani so samo najpogostejši odgovori.

14 Eden od 21 učiteljev, ki so kot največjo težavo navedli strokovne izraze, ni odgovoril na vprašanje o uporabi dvojezičnih virov.
} 
KAKO KORISTNE SO NAŠTETE JEZIKOVNE INFORMACIJE ZA VAŠE POTREBE UPORABE MADŽARSKEGA JEZIKA PRI POUČEVANJU? (N=117)

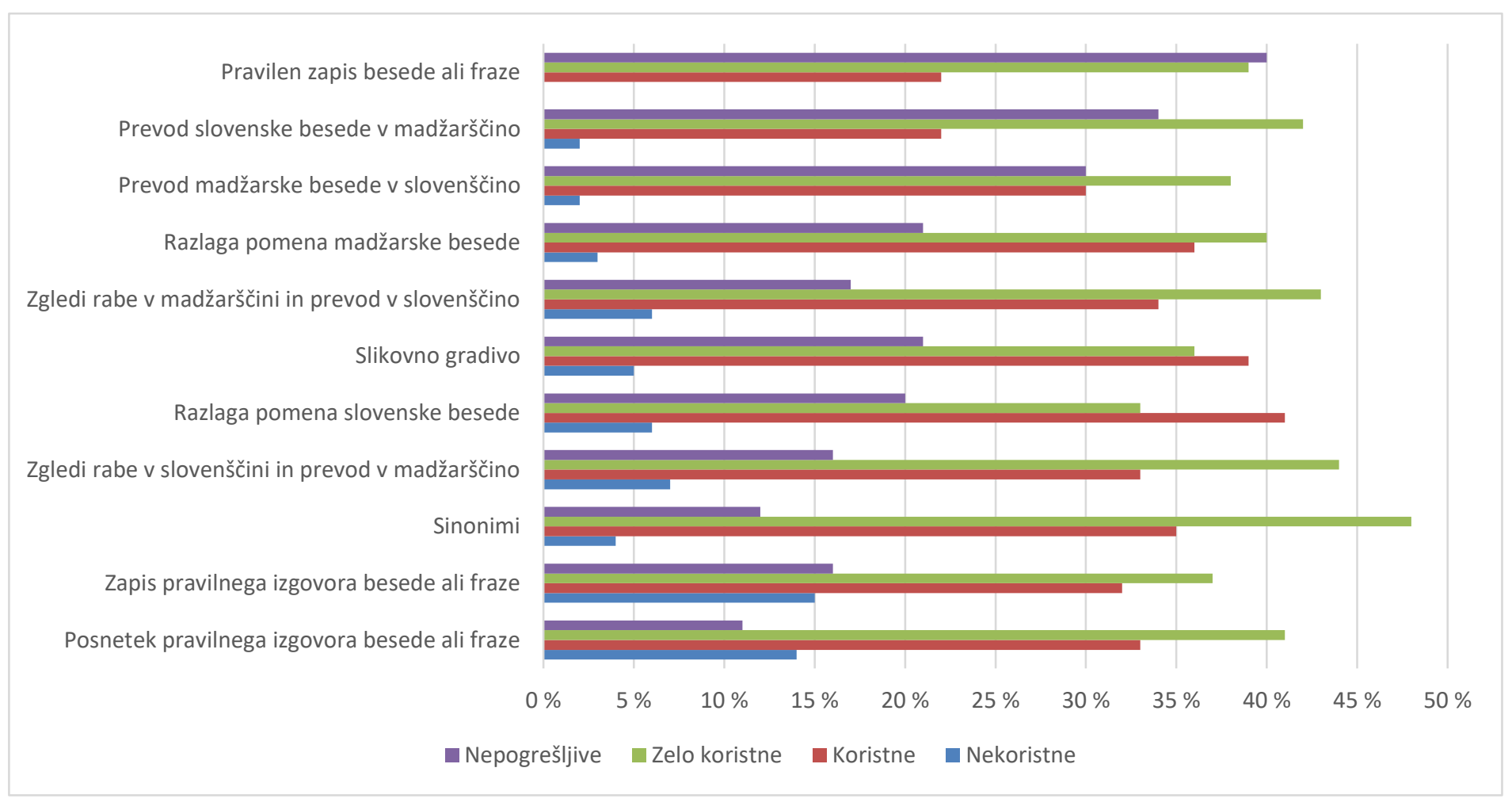


Pri zadnjem vprašanju nas je zanimalo, kako koristne se zdijo učiteljem različne jezikovne informacije $\mathrm{v}$ slovarjih, pri čemer smo navedli tako tiste, ki jih najdemo $v$ jezikovnih virih, naštetih $\mathrm{v}$ anketi, kot $\mathrm{v}$ drugih sodobnih enojezičnih in zlasti dvojezičnih jezikovnih virih. Jezikovne informacije v diagramu so navedene po koristnosti za učitelje glede na povprečje, ${ }^{15}$ od najkoristnejše na vrhu do najmanj koristne na dnu.

Najprej velja izpostaviti, da se prav vse informacije zdijo učiteljem koristne, saj je razlika v povprečju med najkoristnejšo (povprečje 3,2) in najmanj koristno $(2,5)$ majhna, poleg tega pa je povprečje najmanj pomembne informacije med koristno in zelo koristno. Sledi analiza po posameznih tipih jezikovnih informacij, pri čemer komentiramo tako splošni rezultat kot posamezna relevantna odstopanja glede na lastnosti učiteljev oz. njihovo rabo jezikovnih virov:

- $\quad$ Pravilen zapis besede ali fraze $(3,2)$ :

- Za učitelje najkoristnejša informacija (40 \% učiteljev jo ima za nepogrešljivo, 39 \% pa za zelo koristno), in je hkrati tudi edina informacija, ki se nobenemu od učiteljev ni zdela nekoristna. To se tudi ujema s pogosto omembo pravopisa kot ene največjih težav pri sporazumevanju oz. poučevanju.

- Visok pomen mu pripisujejo učitelji, ki nimajo težav pri sporazumevanju v madžarščini (3,3; nepogrešljive, $51 \%$, AR = 2.589), manjši pa učitelji, ki imajo največ težav pri govorjenju (2,9; nepogrešljive, $22 \%, \mathrm{AR}=-1.962)$.

- Nadpovprečno visokemu deležu učiteljev, ki uporabljajo Hradilov navzkrižni slovar, se je informacija zdela nepogrešljiva $(55 \%, \mathrm{AR}=2.831)$.

\footnotetext{
15 Povprečje je izračunano z množenjem števila učiteljev, ki so izbrali določeno vrednost ( Nepogrešljive $=4$, Zelo Koristne $=3$, Koristne $=2$, Nekoristne $=1$ ), in deljenjem s številom vsem učiteljev, ki so odgovorili na vprašanje. (opomba se nadaljuje na naslednji strani)
} 
- Prevod slovenske besede ali besedne zveze v madžarščino $(3,1):{ }^{16}$

○ Velik delež učiteljev, ki imajo informacijo za nepogrešljivo (34 \%), samo 2 \% učiteljev se zdi informacija nekoristna.

- Nekoliko manj koristna od povprečja se zdi informacija uporabnikom Sinonimnega slovarja slovenskega jezika $(2,9)$, statistično pomembna sta deleža uporabnikov Sinonimnega slovarja slovenskega jezika ( $8 \%, \mathrm{AR}=2.607$ ) in Slovenskega etimološkega slovarja, ki se jima zdi informacija nekoristna (11 $\%, \mathrm{AR}=3.020$ ).

- Po drugi strani je statistično pomemben delež uporabnikov SSKJ2, ki ima informacijo za nepogrešljivo ( $41 \%, \mathrm{AR}=2.010)$.

- Z vidika enojezičnih madžarskih virov se informacija zdi nekoliko manj koristna od povprečja (povprečje 2,9) učiteljem, ki uporabljajo slovar sinonimov, in učiteljem, ki uporabljajo slovar Vilme Eöry iz leta 2007.

- Prevod madžarske besede ali besedne zveze v slovenščino $(3,0)$ :

- Samo 2 \% učiteljem se zdi informacija nekoristna.

- Zelo koristna se zdi informacija učiteljem na srednji poklicni šoli $(3,4)$.

- Precej manj koristna od povprečja se zdi informacija učiteljem, ki uporabljajo portal Termania (2,0), malce manj koristna pa tudi uporabnikom portala Fran $(2,8)$, Sinonimnega slovarja slovenskega jezika $(2,8)$, Slovenskega etimološkega slovarja $(2,8)$ in Slovarja tujk $(2,8)$. Statistično pomembne razlike so predvsem pri deležu učiteljev, ki menijo, da je informacija nekoristna (npr. Sinonimni slovar slovenskega jezika, 8 \%, AR = 2.607, Slovenski etimološki slovar, $11 \%, \mathrm{AR}=3.020$ ).

- Informacija se zdi manj koristna od povprečja tudi učiteljem, ki uporabljajo enojezične vire za madžarščino, in sicer

${ }^{16} \mathrm{~V}$ tabeli je zaradi preglednosti del "ali besedne zveze" izpuščen. 
predvsem uporabnikom etimološkega slovarja $(2,5)$, slovarja Vilme Eőry iz leta $2007(2,7)$ ter obeh slovarjev sinonimov $(2,8)$.

- $\quad$ Razlaga pomena madžarske besede $(2,8)$ :

- Statistično pomemben je zelo nizek delež učiteljev, ki uporabljajo SSKJ2 in se jim zdi informacija nekoristna (1\%, $\mathrm{AR}=-2.300$ ), čeprav v celoti gledano uporabniki SSKJ2 ne odstopajo od povprečja.

- Statistično pomemben je tudi visok delež učiteljev, ki nimajo težav s sporazumevanjem v madžarščini in menijo, da je ta tip informacije nepogrešljiv ( $27 \%, \mathrm{AR}=1.964)$.

- Zgledi rabe določene besede $\mathrm{v}$ madžarščini in njihov prevod $\mathrm{v}$ slovenščini $(2,7)$ :

○ Opazno manjši delež učiteljev, ki se jim zdi informacija nepogrešljiva (17\%).

- Manj koristna od povprečja se zdi informacija uporabnikom portala Fran $(2,4)$, pa tudi Sinonimnega slovarja slovenskega jezika $(2,5)$ in Slovarja tujk $(2,6)$.

- Informacija se zdi nekoristna tudi dokaj visokemu deležu učiteljev, ki imajo težave pri pisanju v madžarščini (12 \%), razlika je statistično pomembna $(\mathrm{AR}=2.018)$.

- Nižja od povprečja je tudi povprečna ocena koristnosti učiteljev na srednji poklicni šoli $(2,5)$, statistično pomemben je predvsem visok delež učiteljev, ki se jim zdi informacija nekoristna ( $31 \%, \mathrm{AR}=3.885)$.

- Je pa informacija pomembna za učitelje od 36 do 45 let, saj se prav nobenemu od 41 učiteljev ni zdela nekoristna $(\mathrm{AR}=$ 2.092).

- Zgledi rabe v slovenščini in njihov prevod v madžarščini $(2,7)$ :

○ Zelo podobni rezultati kot za zglede v madžarščini. 
- Višje od povprečja se zdi informacija koristna učiteljem, ki uporabljajo pravopis na helyesiras.akkrt.hu $(3,0)$, statistično pomemben je predvsem visok delež učiteljev, ki imajo informacijo za nepogrešljivo ( $36 \%, \mathrm{AR}=2.459)$.

- Statistično pomemben je tudi relativno visok delež učiteljev, ki imajo težave s pisanjem in menijo, da je ta tip informacije nekoristen ( $\mathrm{AR}=2.432$. $)$.

- Manj koristna od povprečja se zdi informacija učiteljem na srednji poklicni šoli $(2,4)$, statistično pomemben je predvsem visok delež učiteljev, ki se jim zdi ta informacija nekoristna (31 $\%, \mathrm{AR}=3.562$ ).

- Razlaga pomena slovenske besede $(2,7)$ :

○ Učitelji, ki uporabljajo e-zbirke izrazov, vidijo v tej informaciji manj koristi od povprečja $(2,5)$. Statistično pomembna sta visok delež učiteljev, ki uporabljajo omenjeni vir in se jim zdi informacija nekoristna (10 \%, AR = 2.376), in pa nizek delež učiteljev, ki se jim zdi informacija nepogrešljiva (12 \%, AR = 2.196).

- Precej manj koristna od povprečja se zdi informacija učiteljem, ki imajo težave pri govorjenju v madžarskem jeziku $(2,2)$.

- $\operatorname{Sinonimi~}(2,7)$ :

- Čeprav je delež učiteljev, ki se jim zdi informacija nepogrešljiva (12 \%), manjši kot pri ostalih informacijah z enakim ali večjim povprečjem, pa je pri sinonimih najvišji delež učiteljev (48 \%), v primerjavi z ostalimi tipi informacij, izbral možnost "zelo koristne«, nizek pa je tudi delež učiteljev, ki se jim zdijo sinonimi nekoristni (4\%).

- Bolj koristni od povprečja se zdijo sinonimi učiteljem, ki uporabljajo slovar sinonimov na szotar.net $(3,0)$, statistično pomemben je zlasti visok delež učiteljev, ki se jim zdijo 
sinonimi nepogrešljivi (32 \%, AR = 3.100). Podobno velja tudi za učitelje, ki uporabljajo slovar Gáborja Kissa 2015 oz. slovar Ferenca Pusztaija iz leta 2003 (povprečje pri obeh je 2,9), saj jih ima $27 \%(\mathrm{AR}=2.522)$ oz. $23 \%(\mathrm{AR}=2.060)$ sinonime za nepogrešljivo informacijo.

- Statistično pomemben je tudi delež učiteljev, ki uporabljajo Hradilov navzkrižni slovar in se jim zdijo sinonimi nepogrešljiva informacija ( $21 \%, \mathrm{AR}=\mathbf{2 . 3 3 1})$.

- Visok delež učiteljev, ki nimajo težav pri sporazumevanju v madžarščini, meni, da so sinonimi nepogrešljiva informacija (18\%, AR = 2.053).

- Učiteljem na gimnaziji $(2,5)$ in srednji poklicni šoli $(2,4)$ se zdijo sinonimi manj koristni kot učiteljem na osnovni šoli $(2,8)$.

- $\quad$ Slikovno gradivo $(2,7)$ :

- $21 \%$ meni, da je ta informacija nepogrešljiva, $36 \%$ pa meni, da je zelo koristna. Po drugi strani jih le $5 \%$ meni, da je slikovno gradivo nekoristno.

- Manj koristno se v povprečju zdi slikovno gradivo učiteljem, ki uporabljajo slovar sinonimov na szotar.net $(2,5)$. Statistično pomemben je predvsem delež učiteljev, ki sem jim zdi slikovno gradivo nekoristno ( $11 \%, \mathrm{AR}=2.516$ ).

- Zapis pravilnega izgovora besede $(2,5)$ :

○ Veliko učiteljem se zdi informacija nepogrešljiva (16 \%) bodisi zelo koristna (37\%), samo 14 \% jo ima za nekoristno.

- Bolj koristna od povprečja se zdi informacija učiteljem, ki uporabljajo pravopis na helyesiras.akkrt.hu $(2,8)$ oz. terminološki slovar na http://ht.nytud.hu/htonline (2,9). Statistično pomemben je tudi visok delež učiteljev, ki uporabljajo slovar sinonimov na 
szotar.net in se jim zdi informacija nepogrešljiva ( $35 \%$, AR = 2.054).

○ Učiteljem, ki je pri vprašanju o težavah pri sporazumevanju v madžarščini, izbrala odgovor »nimam težav«, se zdi informacija bolj koristna $(2,7)$ kot učiteljem, ki imajo težave pri sporazumevanju.

- Najbolj koristna se zdi informacija učiteljem, starim med 46 in 55 let $(2,8)$, kar 33 \% jo ima za nepogrešljivo, kar je statistično pomembno $(\mathrm{AR}=3.182)$.

- Posnetek pravilnega izgovora $(2,5)$ :

- Veliko učiteljem se zdi informacija nepogrešljiva (11) bodisi zelo koristna (41 \%), samo 15 \% učiteljev jo ima za nekoristno.

- Statistično pomemben visok delež učiteljev, starih med 46 in 55 let, ki ima informacijo za nepogrešljivo $(21 \%, \mathrm{AR}=2.216)$.

Pri zadnjem vprašanju v anketi smo učitelje povprašali o jezikovnih virih (ne samo o tistih, ki so omejeni na par slovenščina-madžarščina), ki so po njihovem mnenju dobro izdelani. S tem smo želeli po eni strani odkriti, kaj učitelji še radi uporabljajo, po drugi pa identificirati morebitne primere dobre prakse, ki bi jih lahko uporabili pri snovanju slovarja. Najpogostejši odgovori so bili duolingo.com, spletni slovarji Pons (http://sl.pons.com/prevod) in dict.com. Duolingo.com je na nek način poveden odgovor, saj gre za spletno stran za učenje jezikov in ne za jezikovni vir; to na nek način tudi kaže na to, kakšne funkcionalnosti jezikovnih virov dandanes učitelji pričakujejo oz. potrebujejo.

\section{RELEVANTNOST REZULTATOV ZA SLOVENSKO-MADŽARSKI SLOVAR}

Analiza ankete ponuja precej zanimivih informacij o rabi jezikovnih virov med učitelji, vendar pa, kot rečeno, je bil glavni namen ankete pridobiti informacije, relevantne za snovanje novega slovensko madžarskega slovarja. $V$ tem razdelku se tako osredotočimo na različne dele slovarskega koncepta in izsledke ankete, 
ki jih bo pri pripravi koncepta smiselno upoštevati.

\subsection{Oblika oz. medij slovarja}

Kot kažejo rezultati ankete, učitelji najraje uporabljajo kombinacijo digitalnih jezikovnih virov (na računalniku) in tiskanih jezikovnih virov. Precej učiteljev, zlasti starejših, celo najraje uporablja tiskane jezikovne vire. Pri interpretaciji rezultatov pa moramo upoštevati dejstvo, da je veliko obstoječih jezikovnih virov za slovenščino in madžarščino na voljo zgolj v tiskani obliki, če pa so že na voljo v elektronski obliki, so plačljivi. To še zlasti velja za dvojezične vire, od katerih je v elektronski obliki na voljo le Hradilov navzkrižni slovar, pa še tega je treba plačati in namestiti na računalnik (torej ni na voljo na spletu). Kot dober pokazatelj potreb oz. želja učiteljev po prosto dostopnih (in ažurnih) spletnih virih lahko vzamemo e-zbirke izrazov, saj jih uporablja precejšen delež učiteljev, zlasti učiteljev na osnovnih šolah.

Rezultati vprašanj o poznavanju oz. uporabi enojezičnih virov za slovenščino in nekoliko manj za madžarščino razkrivajo, da učitelji vire raje uporabljajo ločeno; tako so portali, kot sta npr. Fran in Termania, učiteljem precej manj poznani oz. jih uporablja dokaj malo učiteljev. Sploh slabo poznavanje in uporaba portala Fran med učitelji sta zanimiva v luči izjav avtorjev portala o njegovi uveljavljenosti med vsemi tipi uporabnikov. ${ }^{17}$

$\mathrm{Z}$ vidika slovensko-madžarskega slovarja ti rezultati pomenijo, da mora biti zasnovan za vse oblike, torej za različne digitalne in tiskano. Vseeno pa je treba poudariti, da mora biti slovar primarno zasnovan za digitalni medij, saj je tiskano vedno mogoče izpeljati iz digitalne, medtem ko pri obratnem postopku marsikateri elementi zaradi omejitev tiskane verzije izostanejo (gl. Gorjanc idr. 2015; Krek idr. 2013). Glede na rezultate ankete pa je dobro razmisliti tudi o tem, da je slovar primarno na voljo kot samostojen vir; lahko je sicer tudi

\footnotetext{
17 Primera prispevkov na to temo sta objavi v ZRCalniku (19. 9. 2017, http://zrcalnik.zrcsazu.si/dvajset-milijonov-na-franu-franu-pa-niti-enega-milijona/) in časopisu Delo (25. 9. 2017, http://www.delo.si/kultura/knjiga/dobro-bozanstvo-fran-veliko-dobro-in-zastonj.html).
} 
integriran v portale, ki združujejo več virov, vendar pa ni priporočljivo, da je na voljo samo v tej obliki.

\subsection{Geslovnik}

Pri izbiri geslovnika je po pričakovanjih za učitelje pomembna pokritost strokovnega izrazja, zlasti šolskega. To se kaže tako v virih, ki jih veliko učiteljev uporablja, od e-zbirk izrazov med dvojezičnimi do slovarjev tujk med enojezičnimi, kot v izpostavljanju strokovnih izrazov kot najpogostejši težavi pri uporabi madžarskega jezika pri poučevanju. Pričakujemo lahko, da bo takšno besedišče načrtovani slovar pokril, vendar pa je smiselno v slovarsko bazo vključiti tudi podatke o relevantnosti posameznih gesel oz. pomenov za posamezno področje poučevanja. Pri tem je treba poudariti, da s tem ne mislimo na področne oznake oz. kvalifikatorje v slovarju, ampak na (skrite) področne oznake v bazi (gl. Kosem 2015), ki kasneje omogočajo razna napredna iskanja ali izvoze, npr. samo gesel, ki so relevantna za matematiko. Podobna praksa je v tujini že poznana, npr. opozarjanje na tipično akademske besede (po seznamih, kot je npr. Coxhead 2000) v angleških slovarjih za tuje govorce in prilagajanje zgledov in ostalih vsebin glede na materni jezik uporabnika (Granger in Paquot 2010). Takšne podatke nameravamo pri izdelavi slovenskomadžarskega slovarja pridobiti z analizo šolskih gradiv, kot so učbeniki, delovni zvezki ipd.

Poleg tega je pri izbiri geslovnika treba upoštevati poročanje učiteljev, da jim pravopis povzroča precej preglavic, kar se navsezadnje kaže tudi v tem, da velik delež učiteljev uporablja pravopis, bodisi slovenskega bodisi madžarskega. Posledično je treba pri izbiri geslovnika oz. informacij v geslih razmišljati o vključitvi besedišča ali mikrostrukturnih elementov, ki mogoče kontrastivno niso zanimivi, so pa relevantni zaradi pravopisne zahtevnosti, npr. določene kolokacije, lastna imena ipd.

Upoštevajoč pomanjkljivosti obstoječih dvojezičnih virov za par slovenščinamadžarščina (npr. zastarelost, skromna pokritost) je treba razmišljati tudi o 
načinu objavljanja slovarja. Sodobne leksikografske prakse narekujejo sprotno objavljanje gesel (praksa je že prisotna oz. načrtovana tudi v slovenskem prostoru, gl. npr. iSlovar, ${ }^{18}$ Slovar sodobnega slovenskega jezika, ${ }^{19}$ eSSKJ ${ }^{20}$ ), kar je glede na potrebe učiteljev, pa tudi učencev, vsekakor več kot zaželen pristop pri objavi načrtovanega slovensko-madžarskega slovarja. Poleg tega velja razmišljati o pristopih, ki jih omenja Predlog o izdelavi Slovarja sodobnega slovenskega jezika (Krek idr. 2013), npr. prioritiziranju izdelave gesel (tj. najprej izdelati gesla, ki so za uporabnike bolj relevantna) in vnaprejšnji objavi delno izdelanih gesel. Tako se npr. lahko objavijo gesla, v katerih določeni mikrostrukturni elementi še niso dokončani, npr. vsi zgledi še niso prevedeni. $\mathrm{S}$ tem bi lahko k izdelavi slovarja pristopili v plasteh, tako da bi določenim (obveznim) mikrostrukturnim elementom dali prioriteto, ostale pa bi lahko dodajali sproti.

\subsection{Mikrostruktura slovarja}

Učitelji poročajo o težavah predvsem pri produkcijskih aktivnostih sporazumevanja v madžarskem jeziku (tj. govoru in pisanju). Poudarek na reševanju njihovih težav bi moral biti na spodbujanju pogoste aktivne rabe jezika, utrjevanju znanja pravopisa in bogatenju besednega zaklada, z vidika šolske situacije pa tudi izboljšanju znanja strokovnega izrazja. Zanimivo je, da mnoge enojezične in dvojezične jezikovne vire učitelji, ki nimajo težav pri sporazumevanju v madžarskem jeziku, uporabljajo v večji meri kot učitelji s težavami. To lahko odraža pomanjkljivost obstoječih dvojezičnih virov, ne zgolj $\mathrm{z}$ vidika pomoči pri sporazumevanju, temveč tudi v izobraževalnih situacijah, pa tudi pomanjkanje tovrstnih virov; in ravno slednje je kar nekaj učiteljev tudi izpostavilo kot največjo preglavico pri uporabi madžarskega jezika pri poučevanju.

Vsi tipi jezikovnih informacij, o koristnosti katerih smo spraševali v anketi, se

\footnotetext{
18 http://www.islovar.org/islovar

19 Opisano v Krek idr. (2013) in Gorjanc idr. (2015).

20 http://www.fran.si/201/esskj-slovar-slovenskega-knjiznega-jezika
} 
zdijo učiteljem koristni. $\mathrm{Z}$ vidika snovanja slovensko-madžarskega slovarja to pomeni, da je treba razmišljati predvsem o pripravi oz. vključevanju oblik informacij, ki v obstoječih slovensko-madžarskih slovarjih, pa tudi v ostalih dvojezičnih slovarjih, zaenkrat ne obstajajo ali pa so zelo skromno zastopane, jih pa najdemo v sodobnih dvojezičnih slovarjih, npr. špansko-angleškem ali angleško-španskem slovarju založbe Oxford. ${ }^{21} \mathrm{Tu}$ govorimo predvsem o (celostavčnih) zgledih in njihovih prevodih, posnetkih izgovorjav prevodov (in morebiti tudi zgledov), sinonimih, pa glede na rezultate ankete tudi o slikovnem gradivu. To pomeni, da mora biti precej pozornosti namenjene tudi produkcijski vrednosti slovarja (in ne samo recepcijski).

Še eden od mikrostrukturnih elementov (koristnost katerega sicer $\mathrm{v}$ anketi nismo preverili), ki ga zasledimo v nekaterih sodobnih dvojezičnih slovarjih, so neprevedeni zgledi. Tako npr. že omenjeni špansko-angleški in angleškošpanski slovar založbe Oxford ponujata neprevedene zglede v izvornem jeziku; $\mathrm{v}$ tem primeru je njihova vrednost zgolj za receptivno rabo. V primeru slovensko-madžarskega slovarja bi to pomenilo, da bi imeli neprevedene zglede v slovenščini, namenjeni bi bili predvsem madžarskim maternim govorcem za razumevanje slovenskih besed. Naprednejši pristop so ubrali avtorji estonskofinskega in finsko-estonskega slovarja (Langemets idr., 2017), v katerem bodo uporabnikom na voljo neprevedeni zgledi tako v izvornem kot ciljnem jeziku. Na podlagi predvidevanja, da se besede oz. besedne zveze in njihovi prevodi uporabljajo v podobnih kontekstih, se tako vrednost takšnih zgledov razširi iz receptivne tudi na produktivno.

\subsection{Ostale vsebine}

Učitelji vsekakor uporabljajo širok spekter virov, poleg slovarjev še pravopise, slovarje sinonimov in slovarje tujk. Posledično je smotrno razmišljati o povezovanju slovensko-madžarskega slovarja s tovrstnimi viri, seveda s tistimi, ki so prosto dostopni. Pri tem obstajata dve možnosti: pri prvi, ki je bolj

21 https://es.oxforddictionaries.com/ 
zaželena, pridobimo bazo sekundarnega vira in neposredno integriramo podatke $\mathrm{v}$ slovarsko aplikacijo, pri drugi pa vzpostavimo povezave na geselske članke v sekundarnem viru.

Glede na bogatost in raznovrstnost podatkov, ki naj bi jih vseboval načrtovani slovar, in glede na težave učiteljev pri produkcijskih aktivnostih sporazumevanja $\mathrm{v}$ madžarskem jeziku, je smiselno razmišljati tudi o izrabi podatkov v s slovarjem povezanih ali povsem samostojnih virih. Tako bi lahko na podlagi slovarskih podatkov izdelali vaje za preverjanje, utrjevanje in učenje jezika. ${ }^{22}$ Kot primer vaje za učitelje lahko navedemo vajo izbirnega tipa, pri kateri mora učitelj izbrati pravi madžarski prevod določenega slovenskega strokovnega izraza. Podobno bi lahko naredili tudi za učence, pri čemer bi vaje lahko integrirali v igre (igrifikacija). Izdelava slovarja oz. slovarske baze, ki bi vsebovala številne za ta jezikovni par nove vsebine, pa tudi dodatne vsebine, kot so vaje, je seveda odvisna od razpoložljivih finančnih sredstev, vendar pa pristopi, kot so prioritizacija vsebin in izdelava slovarja v plasteh omogočata lažje prilagajanje obsegu financiranja, ne da bi s tem ogrozili kakovost slovarskega dela in posledično zadovoljitev potreb uporabnikov.

\section{ZAKLJUČEK}

Rezultati ankete prinašajo pomembne informacije o trenutni rabi jezikovnih virov učiteljev na dvojezičnih šolah $\mathrm{v}$ Prekmurju in so pomemben korak $\mathrm{k}$ zapolnjevanju manka raziskav o rabi jezikovnih virov pri nas. Poleg tega, da je anketo izpolnilo precej visoko število učiteljev, je pomembno tudi to, da so bili respondenti zelo heterogeni, tako glede na šolski predmet, ki ga poučujejo, kot glede na stopnjo izobraževanja, na kateri poučujejo. Veseli dejstvo, da velika večina učiteljev pozna razpoložljive jezikovne vire in jih tudi uporablja pri svojem delu. Opažamo tudi, da morajo zaradi težav pri sporazumevanju v madžarskem jeziku učitelji uporabljati širok nabor virov, tako dvojezičnih kot

${ }^{22}$ Primer dobre prakse je spletni portal Vocabulary.com, ki je namenjen predvsem usvajanju besedišča. 
enojezičnih. Pri tem jim ni v pomoč dejstvo, da mnogi viri, zlasti dvojezični, niso na voljo v digitalni obliki.

Čeprav smo anketirali samo učitelje na dvojezičnih šolah, vseeno lahko določena dognanja tudi posplošimo, vsekakor vsaj na učence $\mathrm{v}$ šolah, do določene mere pa tudi na ostale pripadnike dvojezične skupnosti. Treba je namreč vedeti, da so učitelji dober odraz problematike znanja madžarskega jezika na dvojezičnem območju, saj so glavni posrednik tega znanja naslednjim generacijam. Tako lahko pričakujemo, da so ostalim pripadnikom skupnosti poznani podobni jezikovni viri kot učiteljem, pa da imajo tudi podobne težave pri sporazumevanju v madžarskem jeziku. Nekoliko drugačno sliko pri ostalih uporabnikih bi najbrž dobili glede najljubše oblike slovarjev in mnenj o koristnosti delov slovarjev, vendar pa bo načrtovani slovar zasnovan tako, da bo zadovoljil potrebe različnih uporabnikov.

Kljub temu da se rezultate pričujoče ankete lahko deloma posploši, pa je vsekakor treba nadaljevati s podobnimi raziskavami in pridobiti še boljši vpogled $\mathrm{v}$ navade in potrebe dvojezične skupnosti na obeh straneh meje. Tako smo tudi mi skušali opraviti sorodno raziskavo med učitelji v Porabju, vendar pa zaradi skromnega odziva (8 respondentov) rezultatov nismo vključili v ta prispevek; hitra analiza rešenih vprašalnikov sicer kaže na veliko podobnosti v uporabi jezikovnih virov med učitelji v Prekmurju in učitelji v Porabju, najdemo pa tudi nekaj razlik, in sicer zlasti v rabi dvojezičnih virov (npr. manjši delež učiteljev v Porabju kot v Prekmurju uporablja slovar E. Bernjak in e-zbirke izrazov) in mnenju o koristnosti tipov jezikovnih informacij (npr. učiteljem v Prekmurju se niti en tip navedenih jezikovnih informacij ne zdi nekoristen).

Izpostavili smo relevantnost rezultatov ankete za pripravo koncepta in samo izdelavo velikega slovensko-madžarskega slovarja. Gre tako za izbiro oblike slovarja in (delov) geslovnika kot tudi za izbiro elementov slovarske mikrostrukture, še zlasti pomembni pa so razmisleki o vključevanju vsebin, pomembnih za produkcijo besedil oz. govor v madžarskem jeziku, postopnem 
objavljanju slovarja, prioritizaciji gesel in izdelavi gesel v plasteh. Jasno je, da bo slovar moral zadovoljiti potrebe različnih uporabnikov, ne samo učiteljev, toda prednosti digitalnega medija, ki mora biti izhodiščni slovarski medij, in sodobni leksikografski pristopi, kot je npr. izdelava večfunkcijske slovarske baze s podatki za različne uporabnike, dandanes vse to omogočajo.

\section{ZAHVALA}

Prispevek je nastal v okviru ciljno-raziskovalnega projekta Koncept madžarskoslovenskega slovarja: od jezikovnega vira do uporabnika (V6-1509), ki ga sofinancira Javna agencija za raziskovalno dejavnost Republike Slovenije.

Avtorja bi se tudi rada zahvalila ravnateljem dvojezičnih šol, ki so pomagali pri diseminaciji ankete med učitelji, učiteljem za izpolnitev ankete in pa sodelavcem na projektu za pomoč pri pripravi ankete.

\section{LITERATURA}

Arhar Holdt, Š. (2015): Uporabniške raziskave za potrebe slovenskega slovaropisja: prvi koraki. V V. Gorjanc, P. Gantar, I. Kosem in S. Krek (ur.): Slovar sodobne slovenščine: problemi in rešitve, (Zbirka Prevodoslovje in uporabno jezikoslovje): 136-148. Ljubljana: Znanstvena založba Filozofske fakultete.

Arhar Holdt, Š., Kosem, I., Gantar, P. (2016): Dictionary user typology: the Slovenian case. V T. Margalitadze in G. Meladze (ur.): Lexicography and linguistic diversity: proceedings of the XVII EURALEX International Congress, 6-1o September, 2016: 179-187. Tbilisi: Ivane Javakhishvili Tbilisi State University.

Arhar Holdt, Š., Čibej, J., Zwitter Vitez, A. (2017a): Value of language-related questions and comments in digital media for lexicographical user research. International journal of lexicography, 30 (3): 285-308.

Atkins, B. T. S., ur. (1998): Using Dictionaries: Studies of Dictionary Use by 
Language Learners and Translators. Tübingen: Max Niemeyer Verlag. Bela knjiga o vzgoji in izobraževanju v Republiki Sloveniji. (2011): uredila Janez Krek in Mira Metljak. Ljubljana: Zavod RS za šolstvo.

Coxhead, A. (2000): A New Academic Word List. TESOL Quarterly 34 (2): 213-238.

Čibej, J., Gorjanc, V., Popič, D. (2015): Vloga jezikovnih vprašanj prevajalcev pri načrtovanju novega enojezičnega slovarja. V V. Gorjanc, P. Gantar, I. Kosem in S. Krek (ur.): Slovar sodobne slovenščine: problemi in rešitve, (Zbirka Prevodoslovje in uporabno jezikoslovje): 168-181. Ljubljana: Znanstvena založba Filozofske fakultete.

Gomivnik Thuma, V., Milekšič, V., Pisnjak, M., Kumer, I. in László, H. (2010): Spremljanje pouka $v$ dvojezičnih osnovnih šolah na narodno mešanem območju Prekmurja. Poročilo poslano Strokovnemu svetu RS za splošno izobraževanje ter Svetu za evalvacije in kakovost.

Gorjanc, V., Gantar, P., Kosem, I. in Krek, S. ur. (2015): Slovar sodobne slovenščine: problemi in rešitve. Ljubljana: Univerza v Ljubljani, Filozofska fakulteta.

Granger, S., Paquot, M. (2010): Customising a general EAP dictionary to meet learner needs. V S. Granger in M. Paquot (ur.): eLexicography in the 21st century: New challenges, new applications. Proceedings of ELEX2009: 83-86. Cahiers du CENTAL. Louvain-la-Neuve, Presses universitaires de Louvain.

Hozjan, B. (2007): O dvojezičnem šolstvu na narodno mešanem območju Prekmurja. V: Geografija v šoli, Letnik 16, Št. 1: 12-19. Ljubljana: Zavod Republike Slovenije za šolstvo.

Kosem, I. (2015): Oznake: slovarska baza in slovar. V V. Gorjanc, P. Gantar, I. Kosem in S. Krek (ur.): Slovar sodobne slovenščine: problem in rešitve: 
482-494. Ljubljana: Univerza v Ljubljani, Filozofska fakulteta.

Krek, S., Kosem, I. in Gantar, P. (2013): Predlog za izdelavo Slovarja sodobnega slovenskega jezika. Verzija 1.1. http://sssj.si/datoteke/Predlog_SSSJ_v1.1.pdf (dostop 14. 8. 2017).

Langemets, M., Hein, I., Heinonen, T., Koppel, K. in Viks, Ü. (2017): From monolingual to bilingual dictionary: The case of semi-automated lexicography on the example of Estonian-Finnish dictionary. V: I. Kosem idr. (ur.): Proceedings of the 2017 eLex conference: Lexicography from Scratch. 19-21 September 2017, Leiden, Netherlands. Brno: Lexical Computing CZ s.r.o.

Müller-Spitzer, C., ur. (2014): Using Online Dictionaries. Berlin, Boston: De Gruyter Mouton.

Nećak Lük, A. (2013): Metodologija jezikovne organizacije dvojezičnega pouka. V: Priročnik za učiteljev dvojezičnih šol v Prekmurju. Dostopno prek: http://.ekompetencia.si/images/epublikacije/prirocnik/ekompetencia_modszertan_prirocnik_20 131024_splet_kazalo.pdf.

Nesi, H. (2000): The Use and Abuse of EFL Dictionaries. Tübingen: Max Niemeyer Verlag.

Paynter, D. E., Bodrova, E. in Doty, J. K. (2005): For the Love of Words: Vocabulary Instruction that Works. San Francisco: Jossey-Bass teacher.

Pečjak, S. (2012): Psihološki vidiki bralne pismenosti. Od teorije k praksi. Ljubljana: Znanstvena založba Filozofske fakultete.

Tarp, S. (2009): Reflections on lexicographical user research. Lexikos, 19 (1): 275-296. 


\section{USE OF LANGUAGE RESOURCES BY TEACHERS AT BILINGUAL SCHOOLS IN PREKMURJE}

The paper presents the results of a survey on the use of different language resources (dictionaries, orthographies, thesauri, etc.) by teachers at bilingual schools in Prekmurje. The survey was conducted as part of the project focussed on developing a concept of a new comprehensive Slovenian-Hungarian dictionary. The dictionary aims to meet the needs of a wider community, as well as needs specific to bilingual education. The main aim of the survey was thus to establish how well teachers know language resources available to them, how often they use them during their work, and which types of dictionary information do they find useful. Furthermore, the survey also tried to find out which communication activities in the Hungarian language pose most problems to teachers.

The analysis of the survey has shown that majority of teachers know available language resources, and also used them at their work. Due to various problems with communication in Hungarian, teachers need to use a wide variety of language resources, both bilingual and monolingual. The fact that many of the existing resources, especially bilingual ones, are not available in digital form, is definitely a major obstacle. Teachers consider all types of dictionary information to be important/useful, but especially translation equivalents, indication of the correct spelling, explanations of word meanings, and dictionary examples. Importantly, the types of information not available in existing resources, such as audio pronunciation and whole-sentence examples, are considered to be very useful.

The survey findings will be considered in the preparation of a new comprehensive Slovenian-Hungarian dictionary, from headword selection to selecting the parts of dictionary microstructure. However, even more important is the fact that the findings have made us consider a more substantial inclusion of contents relevant for language production, gradual publication of the dictionary, prioritizing the compilation of certain types of entries, and compiling (and publishing) entries in 
layers. Such considerations mean bringing new approaches to Slovenian bilingual lexicography, dictated by lexicographic trends and enabled by state-ofthe-art lexicographic methods.

Keywords: teachers, bilingual education, Slovenian-Hungarian dictionary, survey, use of language resources

To delo je ponujeno pod licenco Creative Commons: Priznanje avtorstvaDeljenje pod enakimi pogoji 4.o Mednarodna.

This work is licensed under the Creative Commons Attribution-ShareAlike 4.0 International.

https://creativecommons.org/licenses/by-sa/4.o/

(c) (i) () 